TITLE:

\title{
INFORMATION ON POLYMERIZATION MECHANISM AND NMR SPECTROSCOPY OF HIGH POLYMERS(Abstract_要旨 )
}

\section{$\operatorname{AUTHOR}(\mathrm{S}):$}

Chujo, Riichiro

\section{CITATION:}

Chujo, Riichiro. INFORMATION ON POLYMERIZATION MECHANISM AND NMR SPECTROSCOPY OF HIGH POLYMERS. 京都大学, 1967, 理学博士

ISSUE DATE:

1967-01-23

URL:

http://hdl.handle.net/2433/212091

RIGHT: 


\section{【52】}

氏名

学位の種類

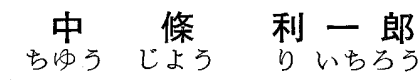

学位記番号

理

学.

博

土

学位授与の日付

論 理 博 第 166 号

学位授与の要件

昭和 42 年 1 月 23 日

学位論文題目

学位規則第 5 条第 2 䐜該当

INFORMATION ON POLYMERIZATION MECHANISM

AND NMR SPECTROSCOPY OF HIGH POLYMERS

(重合機構に関する知見之高分子の NMR 分光学)

論文調査委員教 主授查) 本英 教授富田和久 教授浅井健次郎

\section{論文内容 の 要旨}

高分子とくに二元共重合物の重合過程に找いて生成される高分子の二種モノマ一の組成之配列の制御， また立体規則性高分子の重合ではアイソタクテイック・ヘテロタクテイック・シンデオタクテイックの立 体規則性の配列の制御という問題は，現在の高分子合成化学における重要な問題である。乙の問題の解明 にあたっては，まずそれらの重合過程において生長末端にあらたに結合するモノマーが，生長ポリマーの 末端の性質によって規制されるのかあるいは触媒に内在する性質によって規制されるのか子いった反応過 程の詳細な知識を得なければならない。

申請者は新しく結合するモノマーの活性化エネルギーが生長ポリマーの末端のモノマーに低存して決ま ると考え，その函数として求まる反応確率で作られる二行二列の遷移マトリックスを定義するととによっ て，てれらの重合反応を1つのマルコフ過程として取り报う理論を提示した。

まず二元共重合物（X-Y）の場合には，乙の理論によると，生成高分子の二量体のモル比 $\mathrm{N}_{\mathrm{Xx}} / \mathrm{N}$, $\left(\mathrm{N}_{\mathrm{XY}}+\mathrm{N}_{\mathrm{YX}}\right) / \mathrm{N}, \mathrm{N}_{\mathrm{Y} Y} / \mathrm{N}$ が遷移マトリックスの固有值を用いて表わすことができる。それを用いてモノ マ一反応比を具体的に計算すると，モノマ一反応比が仕込比と二量体モル比で一義的に決まるような関係 式が導かれるととを示した。したがって生成ポリマーの高分解能核磁気共鳴吸収の強度の測定から二量体 モル比が求まる場合には 1 個の試料だけでモノマー反応比が決定されることになる。

申請者は立体規則性高分子に対してての理論を適用した場合に、さらに興味ある結果が得られるととを 示している。すなわち，乙の場合には活性化エネルギーの一次結合で表わされるある特性的な量 $\Delta \varepsilon$ がア イソタクテイック・ヘテロタクテイック・シンデオタクティックの組成比で表わされる関係式を導いた。 これは高分解能核磁気共鳴吸収の測定から得られる量で，その温度依存性を調べるととによって重合反応

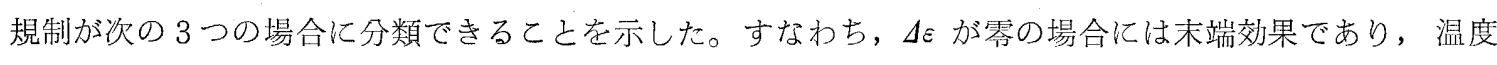
の一次函数の場合にはいわゆるペナルチメイト効果がある場合であり，またある温度の函数で与えられる 場合には触媒効果によるということを結論として見出すととに成功している。 
参考論文は11編あるが, そのうち8 編は高分子の核磁気共鳴吸収に関する実験的研究, ならびに核磁気 共鳴吸収と高分子の構造に関する理諭的研究である。他は高分子固体の結晶化度とそのダイナミカルな性 質に関するもの1編と，高分子固体のガラス転移に関するもの1編と高分子の排除体積効果の統計理論に 関するもの 1 編がある。

\section{論文審查の結果の要旨}

二元共重合物ならびに立体規則性高分子の重合過程に㧍ける成分モノマーの配列あるいは立体規則性の 配列の制御ということは現在の高分子合成化学の重要な問題である。

申請者は重合過程に执いて, 新しく結合するモノマーの活性化エネルギーが，生長末端のモノマーの性 質に依存して決まるとし, その活性化エネルギーの函数として求まる反応確率で作られる二行二列の遷移 マトリックスをもとにして，こ扎の重合反応過程を1つのマルコフ過程として取り扱う理論を提示し た。

まず二元共重合物（X-Y）の場合には，生成高分子の二量体のモル比が遷移マトリックスの固有值を用 いて表わされるととを示し，それを用いてモノマー反応比が仕込比と二量体のモル比 $\mathrm{N}_{\mathrm{XX}} / \mathrm{N},\left(\mathrm{N}_{\mathrm{XY}}+\right.$ $\left.\mathrm{N}_{\mathrm{YX}}\right) / \mathrm{N}, \mathrm{N}_{\mathrm{YY}} / \mathrm{N}$ によって一義的に決められる関係式を導くことに成功した。したがって生成ポリマーの 高分解能核磁気共鳴吸収の強度の測定によって, 二量体のモル比が求められる場合には 1 個の試料の実験 結果を用いてモノマー反応比が決定される。従来は種々の仕込比による多くの試料の解析を必要とした が, 申請者の提出した関係式はこの点において新しい解析法を提示したむのとして重合機構の解明に関す る将来の進歩に寄与するところ大であると考えられる。

さらに申請者は立体規則性高分子に対して, この理論を適用し, 活性化エネルギーのある一次結合で与 えられる特性量 $\Delta \varepsilon$ がアイソタクテイック・ヘテロタクテイック・シンヂオタクテイックの組成比の簡単 な函数で与えられることを示し，高分解能核磁気共鳴吸収の測定によって，ての量を求めたとき， $\Delta \varepsilon の$ 温度依存性を調べるととによって次の 3 つの場合に分類できることを示した。すなおち， $\Delta \varepsilon$ が零のとき には新しく結合するモノマーは末端のモノマーによって規制されるいわゆる末端効果のある場合に相当し， $\Delta \varepsilon$ が温度の一次函数の場合にはペナルチメイト効果が存在する場合であり，触媒効果の場合には $\Delta \varepsilon$ が 温度のある特定の函数になることを明確にした。

この結果は立体規制高分子の重合反応機構に関する知見を得るのに新しい解析法として極めて価值のあ るあのである。じっさい多くの立体規則性高分子についてとの方法による解析が行なわれ上記の分類につ いて調べられ多くの知見がすでに得られている。

参考論文は長鎖状高分子の形態, 高分子固体の相変化, 高分子の核磁気共鳴吸収とその局所的構造など に関する高分子物理学の広い分野にわたっての研究11編よりなっている。

要するに, 主諭文に示された研究は, 高分子の重合反応機構の解明に新しい解析方法を提示したもの で, 高分子重合化学の進歩に寄与するととろ多大である。また参考論文に示された高分子物理学の広い範 囲にわたっての学識と老併せ考えると, 申請者, 中条利一郎の論文は理学博士の学位論文として価值があ るものと認める。 